\title{
Sustainability in Cruise Ship Management
}

\author{
Ruhet Genç ${ }^{1}$ \\ ${ }^{1}$ Vice Dean of the Faculty of Management and Economics, Turkish-German University, Istanbul \\ Correspondence: Assoc. Prof. Dr. Ruhet Genç, Vice Dean of the Faculty of Management and Economics, \\ Turkish-German University, Istanbul.
}

Received: December 24, 2015

Accepted: January 9, 2016

Available online: May 10, 2016

doi:10.11114/ijsss.v4i6.1601

URL: http://dx.doi.org/10.11114/ijsss.v4i6.1601

\begin{abstract}
Cruise tourism flourished and became more popular within last decades with the help of technological advancements in shipping industry and classification of tourism branches in general. Cruise-ships help to solve the need for leisure and the need for place to economic business as well as academic gatherings. While it is expanding rapidly, so the concern about the impact of cruise tourism on the environment in general, port economies \& their sociocultural atmosphere. Any activities whether it is touristic or daily can be specified under the heading of sustainable or non-sustainable. It all depends if we design activities with respect to the future generations or just live from day to day. The research question is how to design sustainable tourism in general and cruise-ship tourism in particular. Food printing compared to environmental loads of cruise tourism and pollution management will be analyzed. The carrying capacity and its current direction will be studied. After discussing about basic terms, some case studies will be given to picture the problematic of cruise-ship tourism. Later on some comparable solutions will be discussed. Towards to the end some suggestions will be given to make the world livable in the future even there is cruise-ship industry's rapid development.
\end{abstract}

Keywords: Sustainable Tourism, Cruise-Ship Tourism, Port Economies, Environmental \& Sociocultural Effects, Pollution Management.

\section{Introduction}

This paper will explore the sustainable tourism practices and the ways to design sustainable cruise tourism. For this aim, environmental and economic effects of cruise tourism will be mentioned. Then the concept of sustainability in cruise tourism will be analyzed in great depth. Waste management and limitations for future research will be given. In the first place the development of cruise tourism and its impact will be mentioned.

Cruise tourism develops basically in the last 40 years. At first Cruise-ship holidays were popular and they were somewhat a kind of luxury for the elite. Whilst twenty years ago the belief was that the days of passenger ships were numbered, their reincarnation as part of the holiday busniness catering for the high-cost, largely American market, has proved to be one of the few profitable sectors in modern day shipping. With an $8 \%$ annual growth since 1980, it has increased at almost twice the rate of tourism overall (Wood, 2000). Simultaneously the idea of sustainable tourism emerges. That is why the principles of sustainability adapted in the cruise industry. There is always room for improvement in sustainable issues. The more we use the cruising service the more we will be aware of the additional problems and want to solve them to make the sector more acceptable and appealing. According to UNWTO Tourism Highlights, 2014 edition between 2003 and 2013 total number of cruise ship beds increased 84.2\% (CLIA (Cruise lines International Association) \& G.P. Wild International Limited).

The cruise industry generated nearly 115 million passenger and crew visit days at ports around the globe. These consisted of 21.32 million passenger embarkations, 71.8 million transit passenger visit days and 21.75 million crew visit days. European ports accounted for $36 \%$ of these while ports throughout North America accounted for $51 \%$ of global passenger and crew visit days. (CLIA, 2013). Two third of the World cruise passangers get on board in North America. They generally travel to Caribbean and Bahamas.

There are almost 1800 ports for cruise ships and most of them are located in Caribbean \& The Bahamas. As a natural outcome Florida is a logical gateway to these destinations. At the same time some other U.S. ports such as Philadelphia, New Orleans, Seattle, Washington, Baltimore, Charleston are also well-known and used for the same purpose. Cruises operate in a very controlled environment. There is an extremely high degree of satisfaction among cruisers, who tend to 
become repeated customers. (Angelo \& Vladimir, 1994).

Cruise ships can also be used as hotels during the mega events such as trade fairs in Düsseldorf. By using cruise ships as hotels during the high seasons prevent unnecessary hotel investments. By doing so they help to maintain sustainability.

A sustainable tourism destination can be reached by inspecting and monitoring quantitative and qualitative changes. Basically the success of tourism activities measured with income earned through such activities. However a handful of researchers are concerned about sociocultural changes, environmental changes and so on. In order to protect the environment you ought to travel and see what you should protect, not to travel is not a solution. But when you travel make sure and make aware of others that every step forward should have sustainability in mind.

Using the LCA (Life Cycle Assessment) methodology cruise tourism impacts include infrastructure impacts, operational impacts, distribution impacts, use impacts and waste impacts (Johnson, 2002). Sustainable strategy has to take into account these impacts and it will be clear that these impacts can be rationalized with a sustainable approach.

Economies of scale (ES) can be used for cruising industry in order to make a sustainable system. In other words average cost decreases as the scale of production becomes bigger. By doing so, less harm per passenger will be given to the environment. Likewise unsold cabins means more negative environmental effects per passenger. It means in order to design a sustainable cruise-ship tourism, one should run the ships full capacity by finding alternative use of cruise diners such as conference venues, business meetings, educational tours, family reunions, cultural activities are only some examples and open tour innovational thoughts. Another way of preventing unsold cabins is to offer low prices to last minute passengers to ensure the sustainable trip.

There are specific issues for the cruise industry and these are importantly in relation with natural and social environmental ones (Dowling \& Vasudavan, 2000). Sustainable Tourism Should;

1) Make optimal use of environmental resources that constitute a key element in tourism development, maintaining essential ecological processes and helping to conserve natural heritage and biodiversity.

2) Respect the socio-cultural authenticity of host communities, conserve their built, living cultural heritage and traditional values contribute to inter-cultural understanding and tolerance.

3) Ensure viable, long-term economic operations, providing socio-economic benefits to all stakeholders that are fairly distributed, including stable employment and income-earning opportunities, social services to host communities, and contributing to poverty alleviation (UNEP \& UNWTO, 2005).

\subsection{Economic Effects}

Economic benefits are coming from several resources; those are a) passengers and crews spending b) operational spending c) ship maintenance and related expenditures d) port spending e) tax spending f) insurances and some other service spending. Many cruise companies prefer to register the ships under the flags of convenient countries in order to minimize paying local taxes and being exempted from paying certain taxes and fees.

\subsection{Environmental Effects}

Whenever there are people, there will always be waste. Especially nowadays our capacity of having wastes increases ranging from packaged materials to technological waste. There are both necessary and unnecessary wastes such as ballast water for first and solid waste for the latter. In order to avoid such threats, improved water safety programs should be applied.

\section{Sustainability}

\subsection{Ecological Sustainability}

For preserving the ecosystems, ecological sustainability has to be taken seriously. Tourism activities use indirectly the ecosystems such as in historical tourism, sea, sand and sun tourism and so on. A sound planning can guide us to have an environmental sustainable tourism.

\subsection{Economical Sustainability}

Sustainable tourism regards the welfare of destination societies by protecting local sources and improving their conditions. Tourism activities may create economic opportunities for the local people and have a contribution to the regional value added. Dwyer and Forsyth had done a study and came up with a framework about the economic factors.

The intensity of demand is the key factor in defining the cruise regions. The actual intensity of demand ranges from the rarely visited or experimental or adventurous cruise areas of Alaska, The Antarctica and The Amazon, to the most frequented or popular cruise destinations of The Caribbean and Mediterranean seas (Ritter \& Schafer, 1998). 


\subsection{Social and Cultural Sustainability}

There are different nations, languages and cultures in the world. Having an awareness and respect for all kinds of differences will bring mutual understanding. Tourism has to take into account the guest and the host social and cultural status into account. The host communities are service providers for tourism industry and social responsibility means the conservation of social and cultural values.

There are different crew members coming from different nations. It is necessary to make them learn sustainability because there is cultural diversity. Cruise Lines International Association is taking social and cultural sustainability seriously. SKAL is the largest professional tourism organization which has a chosen aim to be sustainable in tourism development. SKAL and Cruise Lines International Association are both members of TERN (Tourism Emergency Response Network) designated by UNWTO (Genç, 2015).

\subsection{Ethics}

First of all sustainability is an ethical stance in our thinking and living. Not only in business life and/or tourism but also in every sphere of our lives we have to act having sustainability in our minds. All day long we are leaving the marks of our existence and acts on this planet besides being consumers. In order to reduce these marks and to be a producer while being a consumer, we should give emphasis to the term sustainability.

As being an ethical stance, being sustainable is also a vested interest for businessmen and stakeholders. For the area of cruise tourism, to understand the value of sustainability can be uneasy. All the beautiful sees, oceans, bays and wonders of world seem to exist forever but they actually don't. It may be hard to see the changes in nature in our time perception but not for the careful and sustainability oriented eyes. For being able to organize cruise tourism as of today, the organizers need to accept that the world doesn't have the capacity to erase our marks and to renew itself as fast as we give harm to it.

Dialogues within the same sector and the different ones enable to share or adapt new practices. This leads to a way for improvement and also another way is to identify new opportunities. Researching and analyzing the data to see to the extent that the applications for sustainability have worked so far.

\subsection{Waste Management}

One of the leading companies in cruise-ship sector, The Carnival Cooperation, grouped the waste as regulated waste, food waste, solid waste, hazardous waste and recycled wastes. Regulated wastes are cleaning products and solutions in general. They are transferred to the shore sides that have regulations and license for disposal. Food wastes includes all the eatable things on board. Solid wastes includes all the substances. They are incinerated on board or landed ashore to the appropriate places. Hazardous waste includes all liquid, solid and gas waste that poses risk to human health. They have to be transferred to licensed shore sides. Recycled waste are the materials that is suitable for another use after going under processes. They have to be sorted out. For that both the crew and the passengers can be careful for not blending the recyclable material with the other waste. Recycled waste are broad; plastic, glass, paper, aluminum, batteries are only some examples. From here now on, I will discuss what is used on board. These are fuel, paper, packaging material, food and water, electricity and chemicals.

For sustainability one of the first things to do is to reduce the rate of fuel, greenhouse gas and $\mathrm{CO} 2$ emission ratio from the shipboard operations. Used cooking oils have to be gathered and be taken to a lab and used as a fuel. Another sensitive issue on board is paper. We can ask staff and guests to use less paper and minimize the packaging materials. When purchasing for the kitchen extra attention can be given for choosing absorbent kitchen paper and food and drinks which will be solved in big bulks can be preferred. For advertising alternative methods can be used by reducing paper brochure. Used furniture, clothes and other goods can be donated for the purpose.

Treatment of waste directly on board with the analysis of technologies necessary for creating new products; we can hypothesize above all over the use of the compactors to reduce the volume of paper and create "bricks" of compressed paper which can easily be stored whereas damp paper can be dried and compressed to obtain pellets for burning. Alternatively the paper waste can be transformed into cellulose pulp which can be used as raw material for producing new paper. All possibilities can however be analyzed during the course of the project.

The major risk on board is the water. Water is stored from various ports so there is the risk of contamination. Reduce the rate of water consumed is a good way of sustainability. Waste water has to be classified according to their sources and special attention has to be given to each source. Using shore power which enables ship to turn off ship's diesel engines to minimize air pollution is an effective caution.

Incineration on board and ashes has to be tested whether they are hazardous or not and then should be landed a shore. Inverter climas, efficient machines, led lightining fixtures and hvac (heating ventilation air condition) have to be used. 
Wet cleaning instead of dry cleaning should be used because dry cleaning has lots of chemical materials. Batteries and mercury containing light bulbs should be sent to recycle.

\subsection{Management}

To make cruise-ship industry more appealing and long lasting, management should make sustainability a philosophy of ethics. It requires when necessary changing regulations and evaluating new methods to minimize the environmental impacts. At the same time informing the crew and enable them to have an environmental concerns by organizing regular meetings. Nevertheless there is a study which proves the importance of educating tourists about the wildlife and natural environment (Orams, 1997). It is crucial to enable all employees to have information about their job and job processes (James \& Baldwin, 2003). This requires offering not only personal training but also teaching daily operations (Genç, 2013).

The happiness of employees leads to the happiness of customers (Lashley, 2000). Like this fact the sustainable mind of employees lead to the sustainable mind of employers. The process of recording and analyzing the ship management documents enable keeping track. The technology for green ships, classification of recyclable material and rationalization of materials on board are good practices of environmental sensitivity.

ISO 14001 focuses on the process of how services delivered and products are produced rather than on the actual service or product itself. It also presents a structural approach to setting environmental objectives, targets and provides a framework for organizations to apply these conceptions to their processes. Since many of the cruise ships do have ISO 14001 in order to keep the international standard, they need to comply with related rules and regulations constantly and kept truck to ensure it.

Ship scrapping without extra caution is not sustainable. This process needs to be analyzed and sustainable plans for scrapping the ships must be elaborated. Most of shipbreaking industry is located in developing countries where shipbreakers sell their products to the construction industry (Stopford, 1997). Ship scrapping without caution is not a sustainable act and produces waste. Since there are no rules and regulations concerning sustainability and/or environmental and public health developing countries, not the developed ones, apply for this kind of operation.

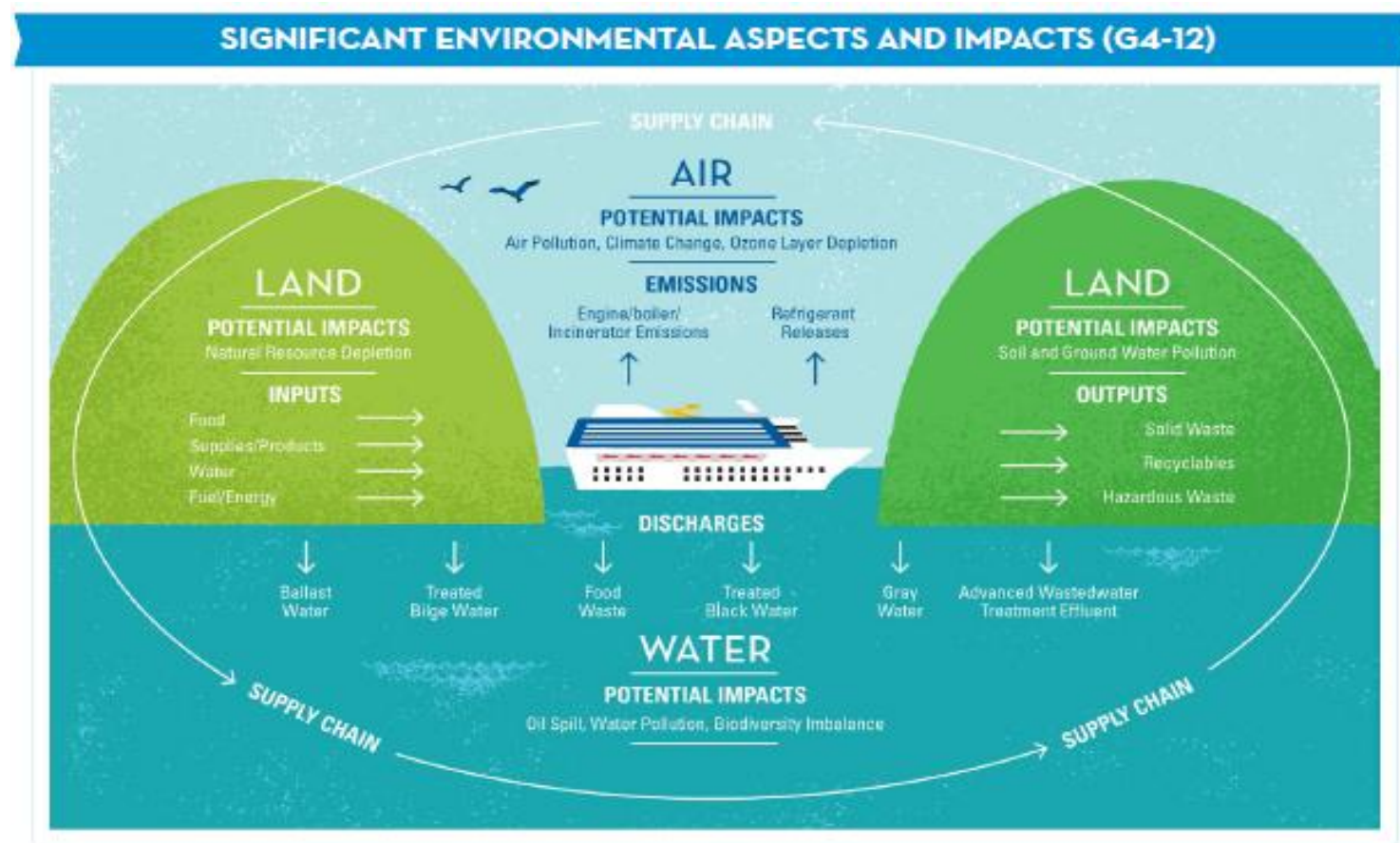

Figure 1. Significant Environmental Aspects and Impacts

Every cruise ship is a system like human body. Of course there will be some intakes in order to live and there will be some outtakes which some are useful and necessary and some others are not environmental friendly and needed to be treated as we can see in Figure 1.

\section{Environmental Regulations}

The OWG (Open Working Group) Sustainable Development Goals allocates sustainability into six categories: people, economy, and society to be developed, and nature, life support and community to be sustained (Global Sustainable 
Development Report, 2015). Whether it is simple data collection or physical participation in conservation activities, these ecotourism holidays have a positive impact on the environment, host community and travellers (Davies, 2002). Sustainability in cruise-ship management is taken into consideration by international bodies. They prefer accepted regulations and put them in power. Some leading international environmental regulations are shown in Table 1.

Table 1. Environmental Regulations

International Convention for the Prevention of Pollution from Ships, 1973 MARPOL To govern and reduce pollution from ship operations

International Management Code for the Safe Operation of Ships and for Pollution An International standard for the safe

Prevention (the ISM Code) management and operation of ships and for pollution prevention

Flag state marine environmental rules and regulations

Port state marine environmental rules and regulations

Directive 2000/59/EC of the European Parliament and of the Council 27 November 2000

Council Directive of 12 December 1991 on hazardous waste (91/689/EEC) amending Directive 78/319/EEC on hazardous waste

U.S. Act to Prevent Pollution from Ships

U.S. Clean Water Act (CWA)

U.S. Vessel General Permit (VGP)

U.S. Clean Air Act (CAA)

U.S. Resource Conservation and Recovery Act (RCRA)

Alaska Cruise Ship Legislation

Hawaii Cruise Ship Legislation

Ballast Water Management Regulations: U.S. Coast Guard, California, IMO, To prevent impacts to marine and aquatic life Canadian, Bermuda and European Nations

Limits on fuel sulfur content

Guidelines such as Memorandum of Understanding Cruise Operations in Washington State, Florida Department of Environmental Protection Memorandum of Understanding, Cruise Lines International Association
Rules and regulations from the places where the ships are registered

Rules and regulations from the countries and areas where we operate

Reduce discharges of generated waste and cargo residues to sea

Defines hazardous waste and how it is managed

Implements MARPOL and governs ship air and water pollution

Sets standards for effluent discharges to bodies of water and territorial waters to prevent pollution

Regulates discharges incidental to the normal operation of vessels

Protects the public from exposure to airborne contaminants that are hazardous to human health

Hazardous waste management regulations

Regulates water, air and waste from cruise ships

Regulates water, air and waste from cruise ships

Requires compliance certificate; sets sulfur content limits

\subsection{Stakeholder Management}

Stakeholders are responsible from and will be affected by the future of the company. Figure, 2 shows the relation between various concerns and their effect on the stakeholders and the company. 


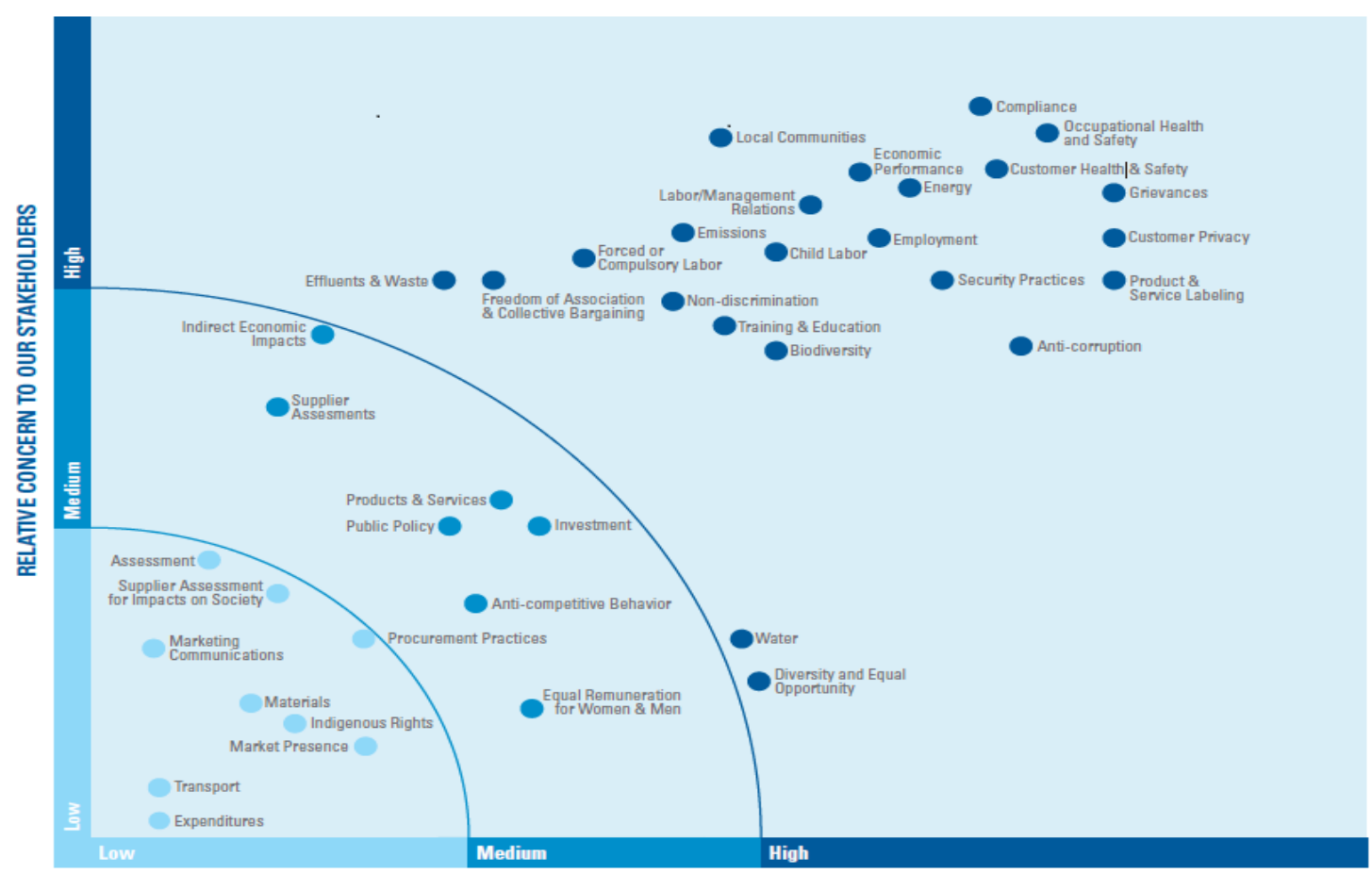

Figure 2. Stakeholder Management Chart

This figure indicates that when the issues related to sustainability are highly concerned by stakeholders and they get highly affected. The more the sustainable issues are concerned, the more the stakeholders positively get affected.

The food sustainable encompasses entire food value chain starting from farmers to processors all the way to consumers. It also covers social, economic and environmental surroundings. Human lives, biodiversity, animal welfare cannot be excluded from sustainability. All these issues should be updated as frequent as necessary.

Table 2. Legislation Pertaining to Marine Pollution

Convention on the Prevention of Marine

Pollution by Dumping of Wastes and Other

Matter (LDC) 1972 amended 1996

International Convention for the Prevention of Pollution from Ships (MARPOL) 73/78

United Nations Convention on the Law of the Sea (UNCLOS) 1982. Part XII. Protection and preservation of the marine environment International Safety Management Code (ISM)

Merchant Shipping (Port Waste Reception Facilities) Regulations 1997

EU Directive: 2000/59/EC. Port reception facilities for ship-generated waste and cargo
Advocates Best Practicable means to reduce pollution and production of harmful wastes. Prohibits deliberate disposal of certain wastes at sea. Categorises waste into black (prohibited) or grey (permit required)

Contains six annexes that prohibit discharges, sets construction standards, imposes penalties, allows for enforcement and identifies 'Special Areas', covering: oil, noxious liquid substances, harmful substances (packaged), sewage, garbage, air pollution.

Articles $194 \&$ \& 195. Includes measures to prevent, reduce and control pollution of the marine environment and to prevent transfer of damage or hazards from one area to another

The mechanism for accountability of mandatory standards as set out in the Ships Management System (SMS). Contains requirements for all vessels to record volumes and types of waste (in accordance with MARPOL 73/78) and method of disposal

Based on findings of Lord Donaldson's report of $1994^{\mathrm{a}}$, which led to improving regulations and enforcement, improving facilities for the legal disposal of waste in ports, increasing penalties for illegal discharge

Covers requirements for port waste reception facilities with the aim of reducing discharges of ship generated waste and cargo residues into the 


$$
\text { residues }
$$

MGN 253 $(\mathrm{M}+\mathrm{F})$. Port Waste Reception

Facilities Regulations 2003 sea by improving availability and use of port reception facilities.

Covers requirements for vessels to report volume and type of waste on board, volume to be discharged or kept on board and mandatory charges for disposal of ship generated waste. (excluding recreational vessels and fishing vessels)

Safer Ships, Cleaner Seas (1994). Report of Lord Donaldson's inquiry into the prevention of pollution from merchant shipping

The International Council of Cruise Lines (ICCL) are the major trade association of the cruise industry, representing 16 major cruise lines which handle approximately $85 \%$ of the worldwide cruise market. Their remit is to monitor domestic and international policy that directly affects the industry to develop recommendations for its members that reflect the policy climate. ICCL have status as a non-government consultative organisation to the IMO and actively participate in helping to develop environmental policy, legislation, conventions and treaties relevant to the industry (UNEP, 2002).

The ICCL have developed an Industry Standard for 'Waste Management Practices and Procedures', which all members have agreed to incorporate into their Ship Management Systems (part of the ISM Code); compliance with this standard will assist in enhancing present cruise-ship waste management (Butt, 2007).

Shipboard waste is streamed according to MARPOL 73/78 Annexes I-VI; which govern pollution control and disposal of ship generated waste and prohibits discharges in designated 'Special Areas'. Waste is streamed as oil, hazardous waste, waste water (black or grey), solid waste and air pollution, falling under MARPOL Annexes I, III, IV, V and VI (Butt, 2007).

Table 3. Disposal options utilised by Onyx Marine

\begin{tabular}{|l|l|}
\hline Recycling & $\begin{array}{l}\text { Oil, oil filters, batteries, aerosols, fluorescent tubes, scrap metal, glass, electronic equipment, } \\
\text { refrigerators }\end{array}$ \\
\hline Incineration & Oily rags, sludge and medical waste \\
\hline $\begin{array}{l}\text { Biological } \\
\text { treatment }\end{array}$ & Bilge water, photochemical waste, sewage and grey water \\
\hline Landfill & General garbage, food waste, incinerator ash (after consolidation and pre-treatment) \\
\hline
\end{tabular}

As an example Onyx Marine, one of the leading companies around the globe also classified disposals in four basic categories as shown in Table 3 . Sustainability requires carrying capacity studies for destinations and hotel development sites be conducted than rigorously implemented through a system of effective planning and operating controls (Gee, 1994).

As another example Carnival Corporation defines their environmental footprint by the significant environmental aspects associated with the operation of their cruise ships. Currently Carnival Corporation with Royal Caribbean International and P\&O Princess Cruises, dominate the business (Johnson, 2002). Carnival Cooperation says;

"We made this strategic choice when we embarked on our sustainability journey, as it is the area we have the greatest control over for making changes and operational improvements. Our impacts include our use of fuel, electricity, water and food; discharge of wastewater; generation and disposal of solid wastes; emissions from combustion and refrigeration equipment; and our divers esupply chain. We also recognize that some of these factors can affect the biodiversity of the areas where we operate.

We continue to seek opportunities to reduce the environmental impacts from our operations by reducing emissions, reducing the generation of waste and implementing conservation initiatives. We have set a corporate target of 20 percent reduction by 2015, from our 2005 baseline, in the intensity of carbon dioxide emissions from shipboard operations and all of our Brands have set ISO14001 objectives and targets."

\subsection{Limitations and Further Researches}

This study has a few limitations. First of all samples are limited. The findings and conclusions are gathered from small groups. This paper focuses on transferrable findings. Bigger samples might have been given healthier results. In another 
study with new points and new data another set of results can be reached.

It is generally accepted that shipping provides the most cost effective and environmentally sound method of transportation for goods worldwide when compared with road, rail and airfreight. But all vessels generate pollution, including waste, which is now legislated through the requirements of the International Convention for the Prevention of Pollution from Ships, 1973, as modified by the Protocol of 1978 (MARPOL 73/78) and the International Safety Management (ISM) Code, both under the auspices of the International Maritime Organisation (IMO). Legislation is also in place through the European Union (EU) relating to the requirements for ports to provide reception facilities for ship-generated waste that cannot be disposed of at sea in compliance with the MARPOL $73 / 78$ regulations (Butt, 2007).

\section{References}

Angelo, R. M., \& Andrew, N. V. (1994). Hospitality today: an introduction. Making Tourism More Sustainable - A Guide for Policy Makers, UNEP and UNWTO, 2005, 11-12.

UNEP. Industry as a partner for sustainable development: tourism. (2002). A report prepared by World Tourism Council, International Hotel and Restaurant Association, International Federation of Tour Operators and the International Council of Cruise Lines; 2002.

Butt, N. (2007). The impact of cruise ship generated waste on home ports and ports of call: A study of Southampton. Marine Policy, 31(5), 591-598.

Cruise Lines International Association, Global Cruise Impact Analysis. (2013). http://www.cruising.org/sites/default/files/pressroom/Global_Cruise_Impact_Analysis_2013.pdf

Carnival Cooperation Sustainability Report. (2013).

Davies, J. (2002). Exploring open spaces and protecting natural places. Journal of Ecotourism, 1(2-3), 173-180.

Donaldson, J. F., Rendle, J., \& McIntyre, A. D. (1994). Safer ships, cleaner seas: report of Lord Donaldson's inquiry into the prevention of pollution from merchant shipping. HMSO.

Dowling, R. K., \& Vasudavan, T. (2000). Cruising in the new millennium. Tourism Recreation Research, 25(3), 17-27.

Dwyer, L., \& Forsyth, P. (1998). Economic significance of cruise tourism. Annals of Tourism Research, 25(2), 393-415.

Gee, C.Y. (1994). International Hotel Management. Amer Hotel \& Motel Assn.

Genç, R. (2013). International Hotel and Restaurant Management. Amazon. com. ISBN 1820433670.

Genç, R. (2015). The contribution of NGOs in general and SKAL International particularly, in tourism development. Asia-Pacific Journal of Innovation in Hospitality and Tourism, 4(1), 113-124.

Le Blanc, David., Roehrl, A., Richard., Ritz, Julie., Jussila, Riina., Plutakhina, Marina., UNEP-DTIE., Zubcevic, Irena., Soltau, Friedrich., Martinho, Maria., O'Connor, David. (2015). Global Sustainable Development Report. Retrieved from https://sustainabledevelopment.un.org/globalsdreport/2015.

International Institude for Sustainable Development. (2015). What is Sustainable Development? Environmental, Economic and Social Well-Being for Today and Tomorrow. Retrieved from https://www.iisd.org/sd/

James, J., \& Baldwin, D. (2003). Streetwise Restaurant Management: A Comprehensive Guide to Successfully Owning and Running a Restaurant. Adams Media.

Orams, M. B. (1997). The effectiveness of environmental education: can we turn tourists into" greenies'?. Progress in Tourism and Hospitality Research, 3(4), 295-306.

Johnson, D. (2002). Environmentally sustainable cruise tourism: a reality check. Marine Policy, 26(4), 261-270.

Ritter, W., \& Schafer, C. (1998). Cruise-tourism: a chance of sustainability. Tourism Recreation Research, 23(1), 65-71.

Stopford, M. (1997). Maritime Economics, 2nd.

Wood, R. E. (2000). Caribbean cruise tourism: globalization at sea. Annals of Tourism Research, 27(2), 345-370.

\section{(c) $)$ EY}

This work is licensed under a Creative Commons Attribution 3.0 License. 